\title{
Franco's Victims in Spain: the Long Road towards Justice and Recognition
}

\author{
Rosa Ana Alija-Fernández and Olga Martin-Ortega
}

\section{Introduction.}

The Civil War that ravaged Spain between 1936 and 1939, after the rebellion of a sector of the army against the democratically elected government of the Second Republic, left a trail of atrocities difficult to quantify. While both sides committed violations, the repression on the rebels' side, headed by General Francisco Franco, was systematic and especially cruel. Their victory on 1st April 1939 marked the beginning of a dictatorial regime -rooted on Franco's leading figure-. After the very intense persecution of political opponents for several years in the aftermath of the civil war, the dictatorship was built on repression of dissidence, restriction of freedoms, and a narrative based on myths that would enhance Franco's role as the saver of the nation. Francoism lasted until Franco's death in 1975. Deprived of its foundational leader and therefore of its sense, the dictatorship was followed by a transitional process that culminated with the adoption of the democratic constitution in 1978. A year before, an amnesty law had been passed as the expression of the political forces" "pact of silence" or "pact to forget".

Today there is still a lack of public discourse recognizing the unbalanced treatment that Franco's victims suffering has had. There have also being limited discussion regarding their legal rights as victims. This article explores this reality by taking a closer look at the elements proposed by Druliolle (2015) in his framework to analyse the politics of victimhood. ${ }^{1}$ Such framework is articulated around two dimensions: the definition of victims (as self-definition, legal definition and socio-cultural factors) and the struggle for legitimacy (p. 321). Our chapter makes a strong emphasis on how socio-cultural factors may determine legal definitions and self-definition of victims. As Druliolle states, victim is primary a legal concept and it is the law -therefore the state- who defines who is a victim. Therefore, it is key to legally identify victims, because from this categorisation derive more than a status, but a set of rights. At the same time, self-definition is critical to boost the struggle for justice and legal recognition. In Druliolle's words, “individuals 
and groups decide whether or not "victim" is a relevant identity, and thus whether they engage in the struggle for legal recognition" (p. 322). Nevertheless, sociocultural factor may be so strong as to ultimately determine both definitions of victims and, consequently, their struggle for recognition and justice.

We argue that in Spain official narratives and amnesty not only resulted in the denial of the legal status of victim but largely in the refusal to self-define as a victim too. At the same time, we suggest that there might be another element in the definition of victims: social definition, that is to say, others' perception of someone as a victim that deserves recognition. In Spain, self-definition might not have been as decisive in the struggle for justice as social definition. The next section analyses how the socio-political and legal structure that followed the civil war deprived Franco's victims of their status as such. This was not only due to their exclusion from the legal category of victims but also to their depiction in the social narrative of the historical events during the Second Republic and the war as well as to their own (self-imposed) social exclusion through silence.

\section{The civil war and the repression that followed: (heroic) victims and (defeated) villains.}

There is little agreement on casualty figures during the war, hundreds of thousands in any event (Juliá, Casanova, Solé i Sabaté, Villarroya \& Moreno, 1999, p. 411; Preston, 2011, p. 17). ${ }^{2}$ While both sides committed atrocities, the repression on the rebels' side was systematic and especially cruel. On the last month of the war, upon the rebels' victory, 20,000 civilians were executed and many more died of starvation and sickness in prisons, concentration and labour camps. Half a million refugees fled to France where they were placed in detention camps. With the outbreak of World War II and the Nazi occupation of France, thousands of Spanish republican refugees were deported to Nazi concentration camps where over 5,000 died.

The dictatorship that followed was -as Aróstegui Sánchez (2009) has put it (p. 41)- a continuation of the civil war itself through all sort of repressive mechanisms. In an impoverished country, lacking essential infrastructure and with the spread of hunger and sickness, post-war repression disposed those on the losing side of their status of victims. The most severe repression took place in the years right after the war and during what is 
commonly referred to as the "triennium of terror" (1947-1949). ${ }^{3}$ Prisons were filled beyond capacity- there were an estimated 280,000 prisoners after the war, most of them held in horrible conditions (Ríos Frutos, Martínez Silva, García-Rubio \& Jiménez, 2008, p. 141). Ten thousand prisoners are estimated to have died of hunger, sickness and inhuman treatment and beatings. Labour camps were also common; according to one estimate, there were 190 camps (Ríos Frutos, et al. 2008, p. 141). ${ }^{4}$ Arbitrary arrests and executions were frequent, as well as summary trials before military judges, with no guarantees and no right to appeal, and death sentences were routinely imposed. Franco's repression resulted in more than 130,000 enforced disappearances (Espinosa Maestre, 2010, pp. 77-78).

Repression was carried out through the establishment of a repressive apparatus and legal system, persecution, purges at all institutional levels, and the imposition of an official narrative of exaltation of the regime and their heroes. A complex normative system was articulated to dismantle the democratic republican legal system, to prohibit political parties and trade unions, to persecute any manifestation of political, religious and ideological dissidence and to establish a totalitarian system (Aragoneses, 2009b, pp. 123159). Freedom of expression, association and peaceful assembly were abolished (Ortiz Heras, 2004, p. 219). Civil and public life was co-opted through -among other thingspublic positions being reserved for those who had fought on the Franco side and friends of the so-called Movimiento Nacional ("National Movement"). The judiciary, for instance, was co-opted and sympathizers were appointed as new judges, prosecutors and court staff. Properties belonging to pro-Republican groups and organizations were confiscated.

Besides, propaganda was an essential tool to justify repression. Francoism built an official narrative where the war was portrayed by the victors as inevitable given the political instability during the last years of the II Republic (Reig, 2006, pp. 97-104; Tamarit, 2013, pp. 42-43). Franco had undertaken a "crusade" against communism to defend the Western Christian civilization (Southworth, 2008, pp. 529-530). ${ }^{5}$ Historians have demonstrated how the narrative of the episodes of the war provided a bias account, based on myths and the manipulation of facts and figures. ${ }^{6}$ The scale of the violations committed by Franco's army was downgraded and even negated. ${ }^{7}$ On the contrary, the violence of the Republican 
army was exalted and given much centrality in the accounts of what had happened during the war.

A story of heroes (the winners) and villains (the defeated) was thus created, resulting in a clearly differential legal and social treatment among victims of the civil war, with the consequence of denying the latter of legal rights of rehabilitation and reparation. The category of "victim" was reserved to those who fought on or sympathised with Franco's side, although without providing a legal definition. ${ }^{8}$ Indeed, during the first years of Franco's regime most of the bodies of those dead in support of Franco and his rebellion were located, exhumed, identified and given burial in their places of origin or in the Valle de los Caídos (the "Valley of the Fallen"), ${ }^{9}$ a pantheon built to commemorate victory. ${ }^{10}$ They were exalted, elevated to the category of martyrs, and their memory turned into national patrimony (Tamarit, 2013, p. 42). Their families were given special status and reparations schemes.

On the contrary, Article 1 of the Law on Political Liabilities (1939) declared "politically liable" -and therefore deserving punishment- those who had contributed to the "red subversion" before the war or had opposed the Movimiento Nacional after the outbreak of the civil war, either through specific acts or through serious passivity. Otherwise said, the democratically elected government of the Second Republic was branded as subversive, and the Republic and its sympathizers, civil servants and ordinary citizens that had not enthusiastically supported the rebellion were criminalized. On this basis, instructed by the Ministry of Justice, the Prosecutor of the Supreme Court initiated in 1940 the Causa General ("General Cause"), to prosecute the crimes committed during the "red domination" (Decreto, 1940). Consistently, the corpses of those killed in battle or assassinated away from the battlefield by Franco's troops and his supporters remained in mass graves in graveyards or on the side of the roads. At the same time, their families were not only deprived of any compensation but suffered further repression, wherein they were marginalized and were denied access to decent jobs.

Coming back to the three factors emphasized by Druliolle to define victimhood (legal definition, sociocultural factors and self-definition), we sustain that the legal framework and the official narrative -attributing the status of victims only to the winners while criminalizing Franco's opponents- conditioned victims' self-definition and their struggle 
for legitimacy. Given the legal and socio-political context, victims had two options: action or passivity. Choosing one or the other would condition self-definition. At this point, we should distinguish between two groups of victims: one including those that actively fought against Francoism, the other encompassing those who did not enter active political resistance (for example, relatives of those directly repressed by Franco, but also victims who had no political affiliation or those that abandoned political opposition after the war). Those who fought the regime clandestinely and tended to self-defined as fighters for freedoms and democracy, or similar, but not as victims. Those who avoided political resistance sought to avoid further repression by hiding their condition as a victim, if they ever self-defined as such. ${ }^{11}$ This group is particularly interesting insofar they resorted to silence as a protective mechanism, as a conscious coping strategy during the dictatorship (Labanyi, 2009, p. 24). In a way, they publicly denied their condition of victim. Privately, "the screen of silence, fear and self-censorship", particularly "in local, rural contexts" (Ferrándiz, 2008, p. 177), makes it hard to know whether they self-defined as victims. ${ }^{12}$ In the light of how events developed in the next decades, it rather seems they did not, as we will discuss later.

\section{The democratic transition and the missed opportunity to recuperate the status of victims.}

The death of the dictator on 20 November 1975 deprived the regime of its inspirational character and meaning and propitiated a change towards democracy. Nevertheless, Francoism was never fully dismantled, but rather adapted to the new political regime. Democracy being rather inevitable, a reformist elite of the old regime would be in control of the process, although opening to negotiation with some opposition parties (Gallego, 2008, p. 411). Indeed, during the transition the most important rules of the new democratic system -among them, the Amnesty Law- were adopted by consensus between the Francoist reformist and the moderates groups of the democratic opposition (Aguilar, 2012, p. 318).

The existing climate of political violence during the transition, ${ }^{13}$ the prevailing traumatic memory of the political violence that preceded the civil war and the shared guilt over the atrocities which had been engraved in the population over forty years of propaganda and manipulation of historical facts, are instrumental in why democratic stability took 
precedence over all other objectives, including accountability for past crimes (Aguilar, 2012, pp. 318-322). ${ }^{14}$ Regarding victims, the democratic transition was a missed opportunity to recognise them such legal status and develop true politics of victimhood. Sociocultural factors were central to understand the lack of a legal definition, the difficulties for self-definition, and why many victims did not struggle for recognition at that time.

The cornerstone of the new political system was the Amnesty Law of 1977, which even preceded the new Constitution (approved by popular referendum in 1978). Amnesty's main aim was to benefit those convicted of political crimes because of their opposition to Franco's regime. It had widespread social backing and was overwhelmingly supported by political parties in the Parliament. ${ }^{15}$ Through amnesty, the political forces steering the transitional process formally gave effect to their agreement not to dwell on the past, but "to look forward." In a more or less implicit way, they also ratified a "pact of silence" over crimes committed by Franco and his regime during and after the Civil War (Tamarit, 2013, p. 62). Whether we accept the argument that silence during the transition was a consequence of a tacit pact, "pact of silence" or not, ${ }^{16}$ the reality is that Spain went through an unwritten political "pact of forgetting". The relationship between the roles of silence and of forgetting ${ }^{17}$ is an important element to consider in the Spanish transition, as it helped building a new official narrative that excluded discussion on victimhood. The very first months and years that followed the death of the Dictator saw a profuse number of demonstrations, publications and debate on the past, the war and its consequences. There was voracity for knowledge and history in the population (Juliá, 2011, pp. 24-28). However, the process of approval of the amnesty regulations, concluded by the first elected Parliament of the democracy, brought what Juliá has described as the first pact of the transition: a pact on the past that, ultimately, prevented it to be used as an instrument in the political fights of the present (Juliá, 2011, p. 39). During the debates to approve normative instruments to declare amnesty, there were recurrent references to the need to forget the past to focus on the present, by all political parties. ${ }^{18}$ Whether we can describe this as a pact to silence or to forget is debatable, but ultimately it brought a sidelining of victims' legitimate struggle for recognition.

Amnesty was presented as a milestone in the reparation and the rehabilitation process of those punished or discriminated for political reasons during the Franco years. In addition, 
amnesty was justified as a tool to prepare the country as a whole for shared life and reconciliation, repairing the wrongs of the past and allowing society to forget and concentrate on the future. But the 1977 Amnesty Law was not a law for victims. The word "victim" is not mentioned a single time in the law, and was never mentioned during the discussions at the Congress (Congreso de los Diputados, 1977). It was a law to pardon, thus confirming the criminal nature of the behaviour of those who had opposed Franco. ${ }^{19}$ Furthermore, it provided protection to perpetrators, implicitly acknowledging the legitimacy of their atrocities. The law contained two provisions that effectively guaranteed impunity for the crimes committed by Franco's regime. Article 2.e) established amnesty for the crimes committed by the authorities and public order agents when investigating and prosecuting political crimes, whilst Article 2.f) contained a general clause of amnesty for crimes committed by civil servants and agents of the public order against the enjoyment of human rights. This pre-constitutional law is still in force and has never been repealed. ${ }^{20}$ Instead, in recent years it has been repeatedly invoked, both in political circles and by the judiciary in order to prevent any potential judicial review of the thousands of crimes committed during the forty years of repression.

Indeed, there was a popular (including many of Franco's victims) claim for amnesty. However, amnesty was supposed to benefit those who were in prison or had been prosecuted for political crimes, the underlying spirit being to release those who had been deprived from liberty for fighting for their freedom. ${ }^{21}$ Nevertheless, not every victim of Franco's repression was a political prisoner: many of those who had suffered the worst repression in the aftermath of the Civil War, or their relatives, or those persecuted for other grounds than political (for example, homosexuals) did not get any advantage from the amnesty. Victims of human rights violations that did not qualify as political crimes, such as the relatives of those executed during the Civil War and the Dictatorship and in general any victim of crimes committed by Franco's public forces (for instance, torture or rape) were not to expect any acknowledgment of their condition as a result of the amnesty. Instead, the official narrative underlined by the Amnesty Law tacitly indicated that their contribution to the transitional pact should be a duty to remain silent and forget, what was perceived as necessary for political stability. The abovementioned victims were never consulted on the terms of amnesty and the transitional pact. However, their part on such pact, their contribution to the construction of democracy was expected to be silence about crimes committed during the Civil War and the Dictatorship by Franco's regime or 
they risked being accused of wanting revenge. It was not hard though to contribute that way to the new democratic project: after forty years being silent, they were well used to do so.

At the same time, any attempt to get justice or reparation done out from the official schemes or to go beyond the accepted claim for amnesty would not only be tagged of "revanchist", but also find either a strong opposition or contempt from public authorities. Initiatives such as the proposal in 1978 to create a Civic International Tribunal against Francoist Crimes ended up with 19 of its promotors (who were politicians of the II Republic, judges, lawyers, professors, young militants, journalists, writers, artists) arrested. ${ }^{22}$ According to the authorities, they were participating in an illegal meeting supported by terrorist group FRAP (Frente Revolucionario Antifascista y Patriota). ${ }^{23}$ In the late 70 s relatives of republican victims privately exhumed some mass graves. But, as Aguilar and Ferrándiz (2016) point out,

they were carried out without any kind of technical (e.g. forensic, anthropological), judicial or economic support; $[\ldots]$ they took place in the absence of any official memory policies; [...] they had very limited (and often no) media exposure and [...] they did not give rise to broader debates regarding Spain's tortuous relationship with its traumatic past.

These initiatives, according to Silva Barrera (2016), did not catch on due to victims' fear, to the lack of political will from political parties in the Parliament, and to the impact of the coup d'état of 23 February 1981, which worked "as a paralyzing conditioned reflex, an order to keep self-repressive behaviours from the dictatorship unalterable in democracy" (pp. 19-20).

Besides amnesty, few measures to address the past regime and dismantle its institutional and legal architecture were adopted in the early years of the transition. As a direct consequence of the nature of a transition made from within, there was no abrupt ideological or personnel break with the previous system (Aragoneses, 2009a, pp. 61-78). Consequently, there was no institutional reform for the vetting of former public officials in civil and military institutions in influential positions. The exit from public and official life of those closer to Franco's regime was facilitated mainly through a progressive succession of early retirements among the military and judicial personnel. Often, 
however, political, military and religious elites continued to occupy important spheres of public life, including the judiciary, the army and the police. The transition also failed to eliminate Francoist symbolism. Monuments, names of many streets and public spaces kept on honouring the "heroes" of the regime, what perpetuated for a long time the distinction between victors and vanquished.

The 1980s saw the beginning of a slow succession of restorative measures, which were however not undertaken as part of a comprehensive scheme of reparation. Some of them included: reintegration of civil servants and military in their former positions, with right to their lost promotions but not to their lost income; recognition of the right of the heirs to receive state pensions and elimination of administrative sanctions that prevented them from accessing state benefits; specific benefits for the so-called niños de la guerra ("children of the war") -children exiled without their parents that had remained in other countries; and devolution of goods confiscated to institutions such as political parties and trade unions, but not to individuals. ${ }^{24}$

In all, the transition failed to change the sociocultural factors (particularly criminalisation and silence) that had turned self-definition of Franco's victims into self-censorship. It also did little to provide them with a generalised (not fragmented) legal status. All this determined the lack (or, at least, the great weakness) of their attempts to justice and recognition in the first decades of democracy.

\section{Struggling for justice and recognition.}

By mid-90s some political discussion on the Civil War and Francoism began at the media, among scholars, and even at the Parliament. ${ }^{25}$ Humlebaek (2004) holds that it was as if all of a sudden a broader public became aware of the existence of a pact to silence or to forget the past. According to him, this was a first symptom that the pact was weakening and political uses of the past were changing (p. 158). At the same time, in the late 1990s and early 2000s a process of revisiting the past and defying the silence that had surrounded the individual stories of many of the victims of the war was initiated by a group of private citizens "searching for their dead." Since then, thousands of bodies have been exhumed, all thanks to the work of private groups and individuals, on occasion at their own expense, and with no official sanction. ${ }^{26}$ This movement is sustained not only 
by those who directly suffered repression but mainly by their grandchildren (born at the end of the dictatorship or early years of the transition), who struggle to understand what happened to the lost members of their families, whose names and stories were buried in silence while they were growing up. The absence of the second generation, or rather their limited role as spectators, is directly related to the imposed silence during the dictatorship to which we referred above (Labanyi, 2009, p. 25). ${ }^{27}$ According to Ortiz Heras (2006), to inoculate in the generation that led the transition a strong "patriotic guilt" concerning the war, implying their co-participation in that big "historical mistake", together with fear and even mistrust to the own exercise of freedoms, was one of the greatest successes of the ideological socialization of Francoism (p. 182).

The exhumations of mass graves encouraged survivors to talk. Ferrándiz (2006) has suggested that the difficulties they find in articulating previously untold experiences is due not to a blocking or failure of memory, but to the habits of silence acquired over so many years. ${ }^{28}$ The reaction of the grandchildren generation against their elders' silence was crucial in igniting and driving a process -now referred to as "recovery of historical memory"- that started with the search for bodies (Labanyi, 2009, p. 25). This has been a process of breaking through the use of history by Franco's regime to create an "official memory" about the time that preceded the civil war, the conflict and the collective guilt over it reflected in the long silence which preceded the transition and was ultimately consolidated by the search for amnesty. As argued before, the victims on Franco's side were key to this memory, their worship being a core element to this construction (Castro, 2008 , p. 165$)^{29}$. Recovering historical memory has also meant attempting to break through the pact of silence during the transition, allowing for a new narrative of consensus over the generalized choice of silence to settle (Gálvez Biesca, 2005, pp. 35-36). The process of recovering historical memory has also attempted to contribute to a renewed process of negotiation over a new-shared collective memory. Overall, the claim has drifted to a broader process of transitional justice that never took place in Spain in a comprehensive way (Álvarez Junco, 2009, pp. 44-45; Capellà i Roig, 2008), including not only the search for truth, but also for justice and reparation.

Most important, as far as Franco's victims are concerned, this process was a turning point to embrace their identity as such. With their grandchildren endorsing them and the physical evidences of Franco's atrocities exposed, they found, as Ferrándiz (2006) puts 
it, "the resonating chamber they had lacked for over 60 years. [...] In this process, the deep silence imposed by Franco's regime on the victims of its terror in the post-war years was markedly shaken" (p. 10). In his opinion, with the exhumations, "survivors were suddenly powerfully anchored in the most explicit evidence of the violence - the corpses themselves" (p. 10). The symbolism in opening the graves, but also the backing of younger generations, the attention of media, and in general a certain social acknowledgement of what they had endured -a "social definition" of their victimhoodseem to have underpin the consciousness of the injustice suffered and their condition as victims.

This breakthrough in self-definition was critical in the struggle for justice and recognition. Particularly, relatives of those killed in the civil war and dictatorship seem to have timidly assumed their own victimhood, although in their narrative they mostly keep presenting themselves as victims' relatives. ${ }^{30}$ One should not disregard either the impact of international human rights law on this new approach. Advances in this field ${ }^{31}$ arguably have strengthened victims' self-definition in Spain, insofar international law provides with a legal definition of victim and therefore with a set of rights, thus adding legitimacy to the struggle for recognition at the domestic system. Nowadays, relatives of those executed and/or enforced disappeared are indeed victims, according to international human rights law. ${ }^{32}$ Instead, by the time the events took place this legal definition did not even exist. As Bassiouni (2006) has shown, international recognition of victims' rights is the result of a process that started after World War II. By the time of the Spanish civil war, Spaniards could not claim for their international recognised human rights, as "human rights violations" did not exist as a legal concept.

The beginning of the exhumation process led to an intensification of political pressure to open public debate and a sustained movement on the parts of the victims to establish their legitimacy. In 2002, Congress passed an institutional declaration reaffirming society's duty to give moral recognition to the victims of the civil war and the subsequent repression (Congreso de los Diputados, 2002). The Declaration, however, declined to assign responsibility for the war and the Franco regime was not condemned. The electoral victory of the Socialist Party in March 2004 brought a propitious climate for further initiatives to recover memory. It established an Inter-ministerial Commission for the Study of the Situation of the Victims of the Civil War and Francoism that should 
recommend measures to compensate and provide for the moral and juridical rehabilitation of the victims of political repression (Real Decreto, 2004, Art. 2).

The struggle for legitimacy was accompanied by great efforts to acquire legal status of victim, mainly through judicial recognition. In 2006 claims reached the Juzgado Central de Instrucción ("Central Investigating Court") of the national court Audiencia Nacional, demanding a judicial investigation of the thousands of enforced disappearances. The claim did not seek individual criminal accountability (Chinchón, 2008, p. 1388) but rather a judicial enquiry over the fate of the missing. In 2008, Central Investigating Judge Baltasar Garzón accepted his jurisdiction over the alleged crimes, which included illegal detention without news of fate (enforced disappearances) committed in the context of crimes against humanity between 1936 and 1951 (Juzgado Central de Instrucción № 5, 2008). His ruling admitted, though, that the exhumations could not be done directly under the competence of his central court, but instead required the cooperation of the local courts at the places where graves were located. Some of them assumed the delegated competence to order the exhumations at local level, but most refused to do so on the basis of either the Amnesty Law or the applicability of statutory limitations to the alleged crimes -despite the permanent character of enforced disappearances ${ }^{33}$-, and systematically taking for granted that the disappeared were dead, without further investigation.

In the meantime, some of the measures in the report adopted by the Inter-ministerial Commission (Comisión Interministerial para el estudio de la Situación de las Victimas de la Guerra Civil y del Franquismo, 2006, p. 22) were included in the Law for the recognition and broadening of rights and establishment of measures in favour of those who suffered persecution or violence during the civil war and the Dictatorship, passed in 2007. This law, also known as the Ley de Memoria Histórica (Historical Memory Law, hereinafter HML) intended to reckon with the past. However, it was firmly grounded on the consensus-to-look-forward narrative -in its own wording, in the spirit of reconciliation and concord that had inspired the transition (preamble). The legislative process shows that there was no political consensus over its need, and that the conservatives considered that it undermined the pact of the transition, aimed to impose a unique and official truth, and was "clearly harmful for the national coexistence" (Congreso de los Diputados, 2007, pp. 14628-14629). ${ }^{34}$ 
According to its preamble, the HML aims to repair victims, consecrate and protect the right to personal and familiar memory, encourage the constitutional, values and promote the knowledge and reflection about the past to prevent similar intolerance and human rights violations. However, its text and the institutional responses fall short of them. Regarding the recognition of victimhood, the main feature of the HML is its meagre use of the term "victim(s)": in the whole text, the word barely appears nine times. In fact, there is no explicit legal definition of "victims". Implicitly, Article 1.1 considers a victim any person that suffered any punishment or violence on political, ideological or religious grounds during the Civil War and the Dictatorship. Article 2.1 generally recognizes and declares the radically unjust character of such punishment or violence. Victims can be granted a "declaration of reparation and personal recognition", although the law expressly states that such declaration does not entitle them to compensation, and declarations will be issued only upon request (LMH, 2007, Art.4). This has been particularly criticized by victims and by jurists for shifting the responsibility for reparation from the State to victims - it is victims' burden to prove the condition and to take the initiative for their legal rights to be recognized (Gil Gil, 2009, p. 97; Martin-Ortega \& Alija Fernández, 2015, pp. 97-114).

There is a timid acknowledgement of the victims' and their relatives' right to personal and family memory. This way, the state is merely guaranteeing a right to talk without shame and fear, but it does not ensure that their stories enter the public domain. No officially-endorsed truth commission is considered. No public policy on memory is designed. Reparations continue to be incomplete and the measures lack a true restorative character, as they are not based on the recognition of the existence of violations of human rights, but rather on some kind of compensatory or equating mechanism (Gil Gil, 2009, p. 97; Chinchón, 2007, pp. 181-183). On the other hand, the HML implicitly endorses the 1977 Amnesty Law by not declaring it repealed, and therefore maintains the rule of impunity and the lack of officially-sponsored investigation of the facts.

In contrast with this somehow propitious legislative climate, in 2008 the Criminal Chamber of the Audiencia Nacional ruled the court incompetent to continue the case on Franco's enforced disappeared and closed the judicial avenue for victims (Audiencia Nacional [Pleno de la Sala de lo Penal], 2008). In a dramatic turn of events, two right 
wing organisations initiated legal proceedings in the Supreme Court against the judge arguing that by assuming jurisdiction over the disappearances he had knowingly issued an unjust decision, a crime under the Spanish Criminal Code. ${ }^{35}$ Paradoxically enough, the trial against Garzón was the only time so far where victims of Francoism had the chance to tell their stories before a court (see, for example, "Dos víctimas de Franco," 2012). Both claims were later dismissed (Tribunal Supremo [Sala de lo Penal], 2012). ${ }^{36}$

The path to justice closed at the domestic level, the victims resorted to the European Court of Human Rights (hereinafter ECtHR). Nonetheless, the result was equally deceiving. In 2012, a chamber of the ECtHR adopted an inadmissibility decision in the first case concerning an enforced disappearance during the Spanish Civil War discussed therein, Antonio Gutiérrez Dorado and Carmen Dorado Ortiz v. Spain. ${ }^{37}$ In their application before the ECtHR, Gutiérrez Dorado and Dorado Ortiz invoked Articles 2 (right to life), 3 (prohibition of torture, and inhuman or degrading treatment or punishment), 5 (right to liberty and security), 8 (right to private and family life) and 13 (right for an effective remedy before national authorities for violations of rights under the Convention) of the European Convention on Human Rights (1950). Focusing on the enforced disappearance of Mr Dorado Luque, the ECtHR considered that the applicants had waited too long before bringing an application before it. According to the court, they should have introduced their complaints without undue delay once it had become apparent that the mechanisms provided by the State no longer offered "any realistic hope of progress in either finding the body or accounting for the fate of their missing relative in the near future" (Antonio Gutiérrez Dorado and Carmen Dorado Ortiz v. Spain, para. 39).

Based on a very strict application of the principle of due diligence in reaching the court, the ECtHR declared the complaint inadmissible. It is questionable that it did not take into consideration how the specific social circumstances -and very centrally their own lack of self-recognition during the repression and the transition, as well as the lack of recognition of their status as victims in domestic law- had determined the victims' behaviour, limiting their agency and ultimately their capacity of diligence in judicial procedures.

Efforts to "get justice done" have not stopped in recent years but on the contrary victims have looked for other fora where to achieve their goal. The most remarkable one was the complaint filed in Argentina by several victims of crimes committed between the 
beginning of the Civil War and the first democratic elections in 1977 (including enforced disappearances and tortures) (Querella 4591/2010, 2010). As far as victimhood is concerned, this initiative is interesting insofar claimants are not only relatives of enforced disappeared during or immediately after the war, but also political activists and opponents persecuted and repressed during later years of the dictatorship. This is a turning point concerning not only the judicial struggle for justice and recognition but also selfdefinition as victims of those who for a long time had defined themselves as fighters for democracy. The Argentinian judge admitted the complaint and, although Spain has so far refused to extradite the alleged perpetrators, her decisions have already had an important effect: following a request of international cooperation issued by the Argentinian judge, on 19 January 2016 took place the opening of the first mass grave under the authorisation of a Spanish judge. Whether the "Argentinian querella" will be successful or not, it will definitely not be the last attempt to achieve justice. ${ }^{38}$ Now that victims have assumed their condition as such, there seem to be more options and strength in the struggle for justice and recognition.

\section{CONCLUSIONS}

Victims of the Spanish Civil War and Dictatorship are on a long road to justice to revert their many years of ostracism and lack of recognition. Following Druliolle's three levels of recognition (self-definition, legal definition and socio-cultural context) for the condition of victim, this chapter has argued that the latter has been critical in Spain. The imposed official memory, together with criminalization, led Franco's victims to a subsequent self-imposed silence (or at least lack of self-definition as victims). The democratic transition, with the Amnesty Law as its cornerstone, ratified a pact of silence or of forgetting within the Spanish society. The official narrative corroborated the narrative of criminalization of Franco's victims. Indeed, no legal definition of victim was articulated, while self-definition was very limited.

Well into democracy, the launching of a movement driven by grandchildren to recover "historical memory" resulted in the opening of mass graves. The symbolic power of exhumations, together with the social backing or social recognition of their victimhood, empowered victims to assume their condition and struggle for legitimacy. With timid and failed- legal attempts to achieve a definition of victims, they have resorted to judicial 
procedures, although obstacles to access them -particularly the Amnesty law- remain. Consequently, inaccessibility of courts has resulted in the denial of the status of victims' and therefore play an integral part of the politics of victimhood in Spain today.

The Spanish case reveals the need for policies of victimhood that take into account social factors that may have led to self-censorship. Victims' silence should not mean they lack legitimacy to claim for their rights. In Spain, this was particularly critical when it came to the admissibility of claims before the ECHR. On the contrary, victims' vulnerability towards social pressure should be overcome either by legal definitions that legitimates their identity and repair their suffering, or by social recognition that backs their struggle. 


\section{Reference list}

Aguilar, P. (2002). Memory and amnesia. Oxford: Berghahn Books.

Aguilar, P. (2008). Políticas de la memoria y memorias de la política. Madrid: Alianza Editorial.

Aguilar, P. (2012). The Spanish Amnesty Law of 1977 in comparative perspective: from a law for democracy to a law for impunity. In L. Payne \& F. Lessa (Eds.), Amnesty in the age of human rights accountability (pp. 325-335). Cambridge: Cambridge University Press.

Aguilar, P., and Ferrándiz, F. (2016). Memory, media and spectacle: Interviú's portrayal of Civil War exhumations in the early years of Spanish democracy. Journal of $\begin{array}{llll}\text { Spanish } & \text { Cultural } & \text { Studies, } & \text { 17(1), }\end{array}$ http://dx.doi.org/10.1080/14636204.2015.1135599.

Ajuntament de Barcelona. (2017, 3 March). L'Ajuntament de Barcelona presenta una querella contra el militar que va signar la pena de mort de Salvador Puig Antich, Press release.

Álvarez Junco, J. (2009). La memoria histórica española. Cursos de Derechos Humanos de Donostia-San Sebastián, X, 43-58.

Aragoneses, A. (2009a). Continuidad y discontinuidad del pasado en la justicia del presente. In F. Fernández-Crehuet López and D. J. García López (Eds.), Derecho, memoria histórica y dictaduras (pp. 61-78). Granada: Comares.

Aragoneses, A. (2009b). El Derecho bajo el Franquismo. Transformaciones del sistema jurídico español (1936-1978). In M. Capellà and D. Ginard (Eds.), Represión política, justicia y reparación. La memoria histórica en perspectiva jurídica (19362008) (pp. 123-160). Palma: Plural.

Aróstegui Sánchez, J. (2009). La Ley de Memoria Histórica: reparación e insatisfacción. Patrimonio cultural de España, 1, 41-60.

Audiencia Nacional (Pleno de la Sala de lo Penal). (2008, 2 December). Procedimiento ordinario núm. 53/08 del Expediente 34/08. Auto.

Bassiouni, M. C. (2006). International recognition of victims' rights. Human Rights Law Review, 6(2) 203-279.

Campelo, P. (2013, 2 December). El Tribunal Internacional contra el franquismo trató de frenar una transición basada en el olvido. Público. 
http://www.publico.es/politica/tribunal-internacional-franquismo-tratofrenar.html. Accessed on 31 March 2017.

Capellà i Roig, M. (2008). La recuperación de la memoria histórica desde la perspectiva jurídica e internacional. Entelequia. Revista Interdisciplinar, 7, 273-279.

Castro, L. (2008). El recuerdo de los caídos: una memoria hemipléjica. Ebre 38. Revista Internacional de la Guerra Civil (1936-1939), 3, 163-197.

Chinchón, J. (2007). El viaje a ninguna parte: memoria, leyes, historia y olvido sobre la guerra civil y el pasado autoritario de España. Un examen desde el derecho internacional. Revista del Instituto Interamericano de Derechos Humanos, 45, 119233.

Chinchón, J. (2008). Examen del Auto del Juzgado de Instrucción No 5 de la Audiencia Nacional por el que se acepta la competencia para investigar los crímenes contra la humanidad cometidos en la Guerra Civil y el franquismo. La Ley: Revista Jurídica Española de Doctrina, Jurisprudencia y Bibliografía, 5, 1388-1397.

Chinchón J., and Vicente, L. (2010). La investigación de los crímenes cometidos en la guerra civil y el Franquismo como delito de prevaricación. Análisis crítico del auto del Tribunal Supremo de 3 de febrero de 2010 desde la perspectiva del derecho internacional. Revista Electrónica de Estudios Internacionales, 19, 1-42.

Comisión interministerial para el estudio de la situación de las víctimas de la Guerra Civil y del Franquismo. (2006). Informe General. http://www.memoriahistorica.gob.es/eses/LaLey/Documents/InformeVictimas.pdf. Accessed on 31 March 2017.

Congreso de los Diputados. (1977). Sesión Plenaria núm. 11 [Proposición de ley de amnistía]. Diario de Sesiones, 24 [Legislatura Constituyente], 953-974.

Congreso de los Diputados. (1995). Proposición no de Ley de los grupos parlamentarios Federal de Izquierda Unida-Iniciativa per Catalunya, Vasco (PNV) y Socialista del Congreso, relativa al reconocimiento de la nacionalidad española por carta de naturaleza a los brigadistas internacionales. Diario de Sesiones - Pleno y Diputación Permanente, 186 [V Legislatura], 9873-9878.

Congreso de los Diputados. (2002). [Institutional declaration]. Boletín Oficial de las Cortes Generales - Serie D, 448 [VII Legislatura], 12-14.

Congreso de los Diputados. (2007). Sesión Plenaria núm. 274. Diario de Sesiones - Pleno y Diputación Permanente, 296 [VIII Legislatura], 14611-14633. 
Congreso de los Diputados. (2016). Proposición no de Ley sobre la modificación de la Ley 46/1977, de 15 de octubre, de Amnistía. Boletín Oficial de las Cortes Generales - Serie $D, 72,24-25$.

Congreso de los Diputados. (2017). [Desestimación de la Proposición no de Ley sobre la modificación de la Ley 46/1977, de 15 de octubre, de Amnistía]. Boletín Oficial de las Cortes Generales - Series D, 80, 9 .

Convention for the Protection of Human Rights and Fundamental Freedoms [European Convention on Human Rights], Nov. 4, 1950, E. T. S. nº 5.

Decreto de 26 de abril de 1940 concediendo amplias facultades al Fiscal del Tribunal Supremo para proceder a instruir "Causa general" en la que se reúnan las pruebas de los hechos delictivos cometidos en todo el territorio nacional durante la dominación roja. B. O. E. 125, pp. 3048-3049 (1940).

Detenidos los asistentes a una reunión “contra los crímenes del Franquismo”. (1978, $\begin{array}{lll}\text { November } 29) . & A B C, & 18 .\end{array}$ http://hemeroteca.abc.es/nav/Navigate.exe/hemeroteca/madrid/abc/1978/11/29/01 8.html. Accessed on 31 March 2017.

Druliolle, V. (2015). Recovering historical memory: a struggle against silence and forgetting? The politics of victimhood in Spain. International Journal of Transitional Justice, 9(2), 316-335.

El Pais, Los promotores del "tribunal contra los crímenes del franquismo", en libertad. (1978, 2 December). El País. http://elpais.com/diario/1978/12/02/espana/281401224_850215.html. Accessed on 31 March 2017.

El Periodico, Dos víctimas de Franco subrayan ante el Supremo que su objetivo es recuperar a sus familiares. (2012, 13 February). El Periódico. http://www.elperiodico.com/es/noticias/politica/tribunal-supremo-comienza-oirtestimonio-victimas-franco-1375261. Accessed on 31 March 2017.

Escudero Alday, R. (2016). Memoria histórica y democracia en España. La brecha de la Transición. México, D. F: Fontamara.

Espinosa Maestre, F. (2010). La represión franquista: un combate por la historia y por la memoria. In F. Espinosa Maestre et al. (Eds.), Violencia roja y azul. España, 19361950 (pp. 17-80). Barcelona: Crítica.

Etxeberria, F. (2016). Exhumaciones llevadas a cabo en España desde el año 2000 (actualizado diciembre 2016). Universidad del País Vasco, Ministerio de la 
Presidencia and Sociedad de Ciencias Aranzadi. http://www.politicasdelamemoria.org/wpcontent/uploads/2015/09/Exhumaciones-desde-el-a\%C3\%B1o-2000-CSIC.pdf. Accessed on 31 March 2017.

Ferrándiz, F. (2006). The return of civil war ghosts: the ethnography of exhumations in contemporary Spain. Anthropology Today, 22(3), 7-12.

Ferrándiz, F. (2008). Cries and whispers: exhuming and narrating defeat in Spain today. Journal of Spanish Cultural Studies, 9(2), 177-192.

Fraser, R. (1979). Recuérdalo tú y recuérdalo a otros. Historia oral de la guerra civil española (Vol. I). Barcelona: Crítica.

Gallego, F. (2008). El mito de la transición. La crisis del franquismo y los orígenes de la democracia (1973-1977). Barcelona: Crítica.

Gálvez Biesca, S. (2005). Las víctimas y la batalla por el derecho a la memoria: la Comisión interministerial para el estudio de la situación de las víctimas de la Guerra Civil y el franquismo. Mientras tanto, 97, 35-52.

Gil Gil, A. (2009). La justicia de transición en España. De la amnistía a la memoria histórica. Barcelona: Atelier.

Gutierrez Dorado and Dorado Ortiz v. Spain, ECtHR, Appl. no. 30141/09, Dec. (2012).

Humlebaek, C. (2004). Usos políticos del pasado reciente durante los años de gobierno del PP. Historia del Presente, 3, 157-167.

International Convention for the Protection of All Persons from Enforced Disappearance, Dec. 20, 2006, 2716 U. N. T. S. 3.

Juliá, S. (2011). Elogio de la historia en tiempos de memoria. Madrid: Marcial Pons.

Juliá, S., Casanova, J., Solé i Sabaté, J. M., Villarroya, J., and Moreno, F. (1999). Víctimas de la Guerra Civil. Madrid: Temas de Hoy.

Junquera, N. (2013). Valientes. El relato de las víctimas del franquismo y de los que les sobrevivieron. Madrid: Aguilar-Santillana.

Juzgado Central de Instrucción $\mathrm{N}^{\mathrm{o}} 5$ (Audiencia Nacional). (2008, 16 October). Diligencias Previas Proc. Abreviado 399/2006 V. Auto.

Labanyi, J. (2009). The languages of silence: historical memory, generational transmission and witnessing in contemporary Spain. Journal of Romance Studies, 9(3), 23-35.

Ley 52/2007, de 26 de diciembre, por la que se reconocen y amplían derechos y se establecen medidas en favor de quienes padecieron persecución o violencia durante 
la guerra civil y la dictadura Congreso de los Diputados [Ley de Memoria Histórica]. B. O. E. 310, 53410-53416 (2007).

Ley de 9 de febrero de 1939, de Responsabilidades Políticas. B. O. E. 44, pp. 824-847 (1939).

Loureiro, Á. G. (2008). Pathetic arguments. Journal of Spanish Cultural Studies, 9(2), 225-237.

Martínez, J. de la C. (1938). ¿Cruzada o rebelión? Estudio histórico-jurídico de la actual guerra de España. Zaragoza: Librería General.

Martin-Ortega, O., and Alija Fernández, R. A. (2015). Where Is My Grandfather? Impunity and Memory in Spain. In E. Bird and F. M. Ottanelli (Eds.), The Performance of Memory as Transitional Justice. Cambridge: Intersentia, pp. 97113.

Orden de 4 de abril de 1940 disponiendo que por los Ayuntamientos se adopten medidas que garanticen el respeto a los lugares donde yacen enterradas las víctimas de la revolución marxista. B. O. E. 96, 2320 (1940).

Ortiz Heras, M. (2004). Instrumentos legales del terror franquista. Historia del Presente, 3, 203-220.

Ortiz Heras, M. (2006). Memoria social de la Guerra Civil: la memoria de los vencidos, la memoria de la frustración. HAOL, 10, 179-198.

Pérez Garzón, J. S., and Manzano Moreno, E. (2010). Memoria histórica. Madrid: Catarata.

Preston, P. (2011). El Holocausto español. Odio y exterminio en la Guerra Civil y después. Madrid: Debate.

Querella 4591/2010, N.N. por genocidio y/o crímenes de lesa humanidad cometidos en España por la dictadura franquista entre el 17 de julio de 1936, comienzo del golpe cívico militar, y el 15 de junio de 1977, fecha de celebración de las primeras elecciones democráticas (2010).

Real Decreto 1891/2004, de 10 de septiembre, por el que se crea la Comisión Interministerial para el estudio de la situación de las víctimas de la guerra civil y del franquismo. B. O. E. 227, pp. 31523-31524 (2004).

Reig Tapia, A. (2006). La cruzada de 1936. Mito y memoria. Madrid: Alianza Editorial. Reig Tapia, A. (2012). La pervivencia de los mitos franquistas. In Viñas, A. (Ed.), En el combate por la historia. La República, la Guerra Civil y el Franquismo (pp. 903920). Barcelona: Pasado y Presente. 
Ríos Frutos, L., Martínez Silva, B., García-Rubio, A., and Jiménez, J. (2008). Muertes en cautiverio en el primer franquismo: exhumación del cementerio del penal de Valdenoceda (1938-1943). Complutum, 19 (2), 139-160.

Sánchez Soler, M. (2010). La transición sangrienta. Una historia violenta del proceso democrático en España (1975-1983). Barcelona: Península.

Silva Barrera, E. (2016). Presentación. In J. Olaso, La represión y las luchas por la memoria en Argentina y España (pp. 19-26). Madrid: Catarata.

Southworth, H. R. (2008). El mito de la cruzada de Franco. Barcelona: DeBolsillo.

Tamarit Sumalla, J. M. (2013). Historical memory and criminal justice in Spain. A case of late transitional justice. Cambridge/Antwerp/Portland: Intersentia.

Tribunal Supremo (Sala de lo Penal). (2012, 27 February). Sentencia 101/2012.

U. N. (1997). Question of the impunity of perpetrators of human rights violations (civil and political). Revised final report prepared by Mr. Joinet pursuant to SubCommission decision 1996/119. E/CN.4/Sub.2/1997/20/Rev.1.

U. N. (2005). Updated set of principles for the protection and promotion of human rights through action to combat impunity. E/CN.4/2005/102/Add.1.

U. N. General Assembly. (2005). Basic principles and guidelines on the right to a remedy and reparation for victims of gross violations of international human rights law and serious violations of international humanitarian law. Resolution 60/147.

Viñas, A. (2012). En el combate por la historia. La República, la Guerra Civil y el Franquismo. Barcelona: Pasado y Presente.

\section{ENDNOTES}

\footnotetext{
${ }^{1}$ In this particular article, Druliolle focuses on the disparity of recognition between Franco's victims and victims of terrorism.

${ }^{2}$ Preston provides the figures of 300,000 men dead in the war fronts and 200,000 civilian, men and women, dead far away from the front (Preston, 2011). More conservative estimates calculate 140,000 people killed away from the battlefield during the war and first decade of the dictatorship -until 1950- (Juliá, et al. 1999).

${ }^{3}$ After that, there were less mass scale human rights violations, but persecution and torture were frequent. Towards the end of the regime, repression was more localised in regions with strong national identity.

${ }^{4}$ The last camp, Los Merinales (Sevilla), closed only in 1962.

${ }^{5}$ Among others, an attempt to legally justify the rebellion as a crusade can be seen in J. de la C. Martínez (1938), pp. 209-210.

${ }^{6}$ Regarding this topic, see generally Viñas (2012).

${ }^{7}$ See e.g., Viñas (2012) or Tapia (2012) on the negation of responsibility over the Guernica bombardment.
} 


\footnotetext{
${ }^{8}$ See an example of such use of "victim" in Orden de 4 de abril (1940).

${ }^{9}$ For initiatives to honour the fallen for Franco see Castro (2008).

${ }^{10}$ Thousands of bodies of republican victims were unburied without the knowledge or authorization of their families and without identification, and reburied latter in the Valle de los Caídos (Gil Gil, 2009, p. 42).
}

11 In their accounts, they often saw themselves simply as relatives, the victims being the death or disappeared ones, or as people who suffered reprisals (represaliados/as). See e.g., Fraser (1979), p. 223; Junquera (2013), pp. 39-43.

12 An important consequence of this is what Labanyi (2009) calls "habits of silence" (p. 24): in Spain, difficulty to find words to articulate previously untold experiences is due to the habits of silence acquired over many years.

${ }^{13}$ On violence during the Transition, see e.g., Sánchez (2010). Focusing on its victims, see Escudero (2016), pp. 125-136.

${ }^{14}$ See generally Aguilar (2002 and 2008). In the first decade of democracy there were over 600 politically related violent deaths perpetrated both by the security forces in the course of police repression of street demonstrations and by extreme left, independentist and right wing organisations (figures in Gil Gil, 2009, p. 45).

${ }^{15}$ The Amnesty Law was the first law adopted by the first democratically elected parliament and the last of the instruments used from 25 November 1975 to provide pardons and amnesty for political crimes. The law was approved by the majority of congress (296 votes in favor, 18 abstentions, 2 votes opposed and 1 invalid vote (Congreso de los Diputados, 1977, p. 974). The abstention came from Alianza Popular, the right-wing party mainly composed by those who had held important positions during the dictatorship, latter transformed in today's Partido Popular (Aguilar, 2012, p. 318).

${ }^{16}$ Loureiro (2008), for instance, considers it a poor metaphor, grounded on an old-fashioned concept of power as an all-controlling force wielded by an elite, in which the populace is confined to a passive or merely reactive role. The transition however, was characterized by a continuous give-and-take between power and resistance, with the many political and popular forces in action striving to reach a balance that would satisfy the majority. The constant strikes and popular demonstrations that caused a stream of steady concessions by Franco's heirs were precisely one of the transition's most notable features (p. 225).

${ }^{17}$ We consider that terminology nuances are important in this point. Here we deliberately distinguish the use of forgetting and oblivion to highlight the difference between the Spanish olvidar as a conscious or unconscious process and olvido, as a place where things that have been forgotten remain.

${ }^{18}$ See for example the analysis of the political negotiations and normative proposals in Juliá (2011), chapter 1).

${ }^{19}$ As Dianne Orentlicher put it in its report on updated principles on human rights and the fight against impunity:

[i]nsofar as it may be interpreted as an admission of guilt, amnesty cannot be imposed on individuals prosecuted or sentenced for acts connected with the peaceful exercise of their right to freedom of opinion and expression. When they have merely exercised this legitimate right, as guaranteed by articles 18 to 20 of the Universal Declaration of Human Rights and 18, 19, 21 and 22 of the International Covenant on Civil and Political Rights, the law shall consider any judicial or other decision concerning them to be null and void; their detention shall be ended unconditionally and without delay (U. N., 2005, pple. 24.c).

${ }^{20}$ In 2016, the parliamentary group Grupo Confederal de Unidos Podemos-En Comú Podem-En Marea filed a proposal to modify the law in order to exclude amnesty over torture, enforced disappearances, genocide and crimes against humanity (Congreso de los Diputados, 2016). The Comission of Justice of the Spanish Congress rejected the proposal (Congreso de los Diputados, 2017). 
${ }^{21}$ This was a general trend in the 70s, when amnesty for political prisoners became a symbol of freedom (U. N., 1997, para. 2).

${ }^{22}$ See press articles "Los promotores" (1978); Campelo (2013).

${ }^{23}$ See the official communiqué in press article "Detenidos los asistentes" (1978).

${ }^{24}$ For a comprehensive list of legal instruments adopted between 1976 and 1999 establishing these and other measures, see Gil Gil (2009), pp. 57-72.

${ }^{25}$ See, for example, Congreso de los Diputados (1995).

${ }^{26}$ Between 2000 and 2016, over seven thousand six hundred exhumations had taken place (Etxeberria, 2016).

${ }^{27}$ There are of course examples of second-generation people (born in the late 1950s) who chose to break the silence that their parents maintained, sometimes until their deaths. Labanyi (2009) suggests this was done out of a retrospective sense of guilt at having done nothing to alleviate their parents' suffering under the dictatorship (p. 25). The silence of the second generation has received practically no attention from scholars.

${ }^{28}$ Ferrándiz has highlighted how, in other cases, the capacity for detailed recollection is extraordinary in people talking for the first time about what they suffered in and after the war (Ferrándiz, 2006, p. 10).

${ }^{29}$ Junquera (2010) even asserts that historical memory was an invention of Franco (pp. 16-17).

${ }^{30}$ See e.g., the testimonies collected in Junquera (2013).

${ }^{31}$ See generally U. N. General Assembly Resolution 60/147 (2005).

${ }^{32}$ See in particular Article 24 of the International Convention for the Protection of All Persons from Enforced Disappearance (2006).

${ }^{33}$ Enforced disappearances are a serious violation of human rights of a continuous nature until the fate of the disappeared person is determined. Accordingly, no statutory limitations apply before that moment. See Article 8.1.c) of the International Convention for the Protection of All Persons from Enforced Disappearance (2006).

${ }^{34}$ Instead, some local nationalist and left wing parties were disappointed over the timid measures. In their opinion, they did not go far enough in the establishment of a framework to pursue truth, justice and reparation (Congreso de los Diputados, 2007).

${ }^{35}$ The Supreme Court decision to accept jurisdiction over the claims has been severely criticized at political level but also considered unsustainable from a legal point of view (Chinchón \& Vicente, 2010).

${ }^{36}$ The Supreme Court established that the Judge was not criminally responsible but had acted wrongly, as he should had applied the Amnesty Law and abstained from ordering the investigation of the disappearances.

${ }^{37}$ The applicants, Antonio Gutiérrez Dorado and Carmen Dorado Ortiz (who died in 2010, before the decision was issued), were grandson and daughter respectively to Luis Dorado Luque, a Member of the Spanish Parliament belonging to the socialist party that had been forcibly taken away on 18 July 1936 by military forces in circumstances that have not yet been fully established. The applicants had no reliable information as to their relative's fate after 28 July 1936. In early August 1936 the body of a person who according to the autopsy had died as a result of firearm injuries with serious wounds to the brain and liver was discovered with documents with Dorado Luque's name in his pockets. Initially registered as Dorado Luque in the civil registry, some days later the judge decided that there was not enough evidence regarding his identity, so they made a new entry in the civil registry was made stating the body was that of an "unknown man". In 1981 her widow initiated a procedure for voluntary declaration of death in order to be entitled to widow's benefits. In 1993 a court confirmed that Mr Dorado Luque had disappeared and that his 
fate and whereabouts were unknown and ordered that his death (established on 30 July 1936) be recorded in the civil registry books. In May 2006 Carmen Dorado brought a criminal complaint that was dismissed on the basis of statutory limitations. The appeal court and the Constitutional Court confirmed the initial decision. In December 2006 Ms Dorado was among the applicants filing the complaint before the Audiencia Nacional on which the decision on lack of jurisdiction was issued in 2008.

${ }^{38}$ For instance, on 3 March 2007, the town hall of Barcelona announced it would file a complaint against one of the jurists in the court-martial that sentenced Salvador Puig Antich to death (Ajuntament de Barcelona, 2017). Puig Antich was the last person executed with garrotte vil in the dictatorship. 